\title{
Determination of organic acids and carbohydrates in 'Salustiana' orange fruit from different rootstocks
}

\section{Determinação de ácidos orgânicos e carboidratos em frutos de laranjas 'Salustiana' provenientes de diferentes porta-enxertos}

\author{
Deived Uilian de Carvalho1* (1), Maria Aparecida da Cruz', Ronan Carlos Colombo², \\ Lycio Shinji Watanabe ${ }^{3}$, Zuleide Hissano Tazima ${ }^{4}$, Carmen Silvia Vieira Janeiro Neves ${ }^{1}$ \\ ${ }^{1}$ Universidade Estadual de Londrina (UEL), Departamento de Agronomia, Londrina/PR - Brasil \\ 2Universidade Tecnológica Federal do Paraná (UTFPR), Centro de Ciências Agrárias, Francisco Beltrão/PR - Brasil \\ ${ }^{3}$ Universidade Estadual de Londrina (UEL), Departamento de Química, Londrina/PR - Brasil \\ ${ }^{4}$ Instituto Agronômico do Paraná (IAPAR), Área de Fitotecnia, Londrina/PR - Brasil
}

${ }^{*}$ Corresponding Author: Deived Uilian de Carvalho, University of Florida (UF), Institute of Food and Agricultural Sciences, Southwest Florida Research and Education Center, 2685 State Road 29 North, ZIP Code: 34142, Immokalee/FL - USA, e-mail: deived10@gmail.com

Cite as: Carvalho, D. U., Cruz, M. A., Colombo, R. C., Watanabe, L. S., Tazima, Z. H., \& Neves, C. S. V. J. (2020). Determination of organic acids and carbohydrates in 'Salustiana' orange fruit from different rootstocks. Brazilian Journal of Food Technology, 23, e2018329. https://doi.org/10.1590/1981-6723.32918.

\begin{abstract}
This study aimed to determine carbohydrates and organic acids in fruit from 'Salustiana' orange tree [Citrus sinensis (L.) Osb.] grafted onto different rootstocks using the HPLC technique, as well as to evaluate their physicochemical properties. As rootstocks, we tested 'Rangpur' lime, 'Cleopatra' mandarin, 'Sunki' mandarin, 'Swingle' citrumelo, and 'C-13' citrange. Fully mature fruit was first characterized according to their physicochemical parameters as fruit mass, longitudinal and equatorial diameters, peel color, juice yield, soluble solids, titratable acidity, and ratio. Then, freshly squeezed juice was used to determine and to quantify organic acids and carbohydrates by the HPLC system. All analyses were performed in triplicate complete randomized with five treatments (rootstocks). Fruit from all evaluated rootstocks presented adequate physicochemical attributes, meeting the quality standards of the citrus industry. 'C-13' citrange induced in a production of large-sized fruit whereas 'Rangpur' lime promoted higher soluble solids content in its juice. Significant differences were not observed between the treatments with regards to organic acids and carbohydrates concentrations. Citric and ascorbic acids were identified and quantified in the juice samples. The sugars identified were sucrose, glucose, and fructose. Organic acids and carbohydrates concentrations are consistent with those reported in the literature for citrus juice, providing information about nutrition and quality of 'Salustiana' sweet orange produced onto different rootstocks.
\end{abstract}

Keywords: Citrus spp.; Fruit quality; Orange juice; HPLC; Organic acids; Sugars.

\section{Resumo}

Este estudo objetivou determinar carboidratos e ácidos orgânicos presentes em frutos de laranjeira 'Salustiana' [Citrus sinensis (L.) Osb.], enxertada sobre diferentes porta-enxertos utilizando técnicas de HPLC, assim como suas propriedades físico-químicas. Como porta-enxerto, foram testados limão 'Cravo', tangerina 'Cleópatra', tangerina 
'Sunki', citrumelo 'Swingle' e citrange ' $\mathrm{C}-13$ '. Os frutos completamente maduros foram caracterizados de acordo com seus parâmetros físico-químicos, como massa de fruto, diâmetros longitudinal e equatorial, cor da casca, rendimento de suco, sólidos solúveis, acidez titulável e ratio. Em seguida, o suco fresco extraído foi utilizado para determinar e quantificar os ácidos orgânicos e carboidratos pelo sistema de HPLC. Todas as análises foram realizadas em triplicata inteiramente casualizada com cinco tratamentos (porta-enxertos). Os frutos de todos os porta-enxertos avaliados apresentaram parâmetros físico-químicos adequados, atendendo aos padrões de qualidade da indústria de citros. $\mathrm{O}$ citrange ' $\mathrm{C}-13^{\prime}$ induziu a produção de frutos de tamanho maior enquanto o limão 'Cravo' promoveu maior teor de sólidos solúveis em seu suco. Não foram observadas diferenças significativas entre os tratamentos em relação às concentrações de ácidos orgânicos e carboidratos. Os ácidos cítrico e ascórbico foram identificados e quantificados nas amostras de suco. Como açúcares, foram identificadas sacarose, glicose e frutose. As concentrações de ácidos orgânicos e carboidratos são consistentes com àquelas reportadas na literatura para sucos cítricos, fornecendo informações sobre nutrição e qualidade de frutos da laranjeira 'Salustiana' sobre diferentes porta-enxertos.

Palavras-chave: Citrus spp.; Qualidade de fruto; Suco de laranja; HPLC; Ácidos orgânicos; Açúcares.

\section{Introduction}

Brazil leads the worldwide production of oranges, which ensured an annual production of 17.3 million tons in 2016, responsible for $25 \%$ of the total production (Food and Agriculture Organization Corporate Statistical Database, 2018). About $80 \%$ of its production goes to the industry, mainly to process frozen concentrated orange juice (FCOJ) for exportation and the remaining (20\%) is destined to supply the Brazilian fresh market. For this reason, the production of orange cultivars intended for the fresh and processing purpose has increased, because of the advantage of dual decision making and flexibility to the citrus growers.

By this context, the sweet orange cv. Salustiana [Citrus sinensis (L.) Osb.] has excellent performance for both purposes, but mainly for in natura consumption because its fruit is seedless, very taste (Castle \& Baldwin, 2011) and has suitable physicochemical characteristics according to the fruit quality standards (Organisation for Economic Co-operation and Development, 2010; Companhia de Entrepostos e Armazéns Gerais de São Paulo, 2011). Nevertheless, physicochemical quality may appear divergent in their values according to the rootstock used for citrus cultivation.

Some authors have reported this influence on fruit quality in several citrus cultivars (Cantuarias-Avilés et al., 2010; Gonzatto et al., 2011; Legua et al., 2011; Silva et al., 2013; Tazima et al., 2014; Bacar et al., 2017). Similarly, Castle (2010) confirms that rootstocks are highly related to many fruit attributes such as fruit size, and juice quality in which sugars and acids are affected, being a major factor for growers of fresh and processing fruit. In this way, it is important to assay new alternatives of rootstocks to diversify citrus groves and verify their influence on fruit quality.

As far as the physicochemical quality of citrus is important for commercialization and consumption, the description of their compounds profile is required, because the general composition and antioxidant properties of foodstuff are critical to determine consumer acceptance and preference. Carbohydrates and organic acids are among the major compounds present in citrus fruit, and their nature and concentration largely affect taste characteristic and organoleptic quality (Kelebek et al., 2009).

According to Lado et al. (2014), the total soluble solids content present in citrus fruit is composed of about $80 \%$ of carbohydrates, $10 \%$ organic acids, and $10 \%$ nitrogenous compounds. Thus, sweet oranges present a high amount of sugars and their sweetness is intrinsic to their composition (Kelebek et al., 2009). They are compounded mainly by sucrose, the major sugar component, glucose, and fructose, and their ratio is usually 2:1:1 respectively (Lee \& Coates, 2000).

Organic acids are the second major group of natural compounds present in oranges. Their nature and concentration in fruit are important to the fresh market and industry, because they greatly influence the 
organoleptic properties and stability of fruit juices, being an important index to determine fruit authenticity (Kelebek et al., 2009; Scherer et al., 2012). However, their profile and concentration in citrus fruit are related to sugar content and are dependent on citrus varieties, soil, climate, and stress conditions (Jones, 1998; Lado et al., 2014). In general, citric, ascorbic, and malic acids are the most abundant organic acids found in sweet orange. According to Scherer et al. (2012) citric and malic acids are commonly used as acidulants to enhance beverages and ascorbic acid as an antioxidant.

By this context, this study aimed to determine carbohydrates and organic acids in fruit from 'Salustiana' orange tree grafted onto different rootstocks using HPLC techniques, as well as, to analyze other physicochemical characteristics.

\section{Materials and methods}

\subsection{Chemicals}

We used ultra-pure water, Milli-Q quality (Simplicity 185, Millipore, USA) to prepare samples and solutions. For organic acids, we used ascorbic and citric acid standards (Sigma-Aldrich, Saint Louis, USA) with purity $>98 \%$; while carbohydrate standards were: sucrose (Synth, São Paulo, Brazil), D-(+)-glucose and D-(-)-fructose (Merck, Darmstadt, Germany) with purity levels of 98.9\%, 99.5\%, and 99.9\%, respectively. And all other chemicals were HPLC quality.

\subsection{Sample collections}

Fully mature oranges from the mid-season cv. Salustiana [Citrus sinensis (L.) Osb.] grafted onto five rootstocks were manually harvested in July 2017 from the experimental station of the Instituto Agronômico do Paraná (Londrina-PR, Brazil), when fruit exhibited suitable maturation index, superior to the minimum index (9.5) established by the domestic marketing (Companhia de Entrepostos e Armazéns Gerais de São Paulo, 2011), indicating the harvest point. As rootstocks, we tested 'Rangpur' lime (C. limonia Osb.), 'Cleopatra' mandarin (C. reshni Hort. ex Tanaka), 'Sunki' mandarin (C. sunki Hort. ex Tanaka), 'Swingle' citrumelo [C. paradisi Macf. cv. Duncan $\times$ Poncirus trifoliata (L.) Raf.] and 'C-13' citrange [C. sinensis (L.) Osb. $\times$ P. trifoliata (L.) Raf.]. 'Salustiana' oranges (10 fruit per tree) were collected from different trees (12 year-old), packed in plastic boxes (industrial standard: maximum capacity of $40.8 \mathrm{~kg}$ ), and transported immediately to a cold chamber to pre-cooling for $12 \mathrm{~h}$ at $4 \pm 1{ }^{\circ} \mathrm{C}$ and $90 \% \mathrm{RH}$ in the Agricultural Science Department of the Universidade Estadual de Londrina (Londrina-PR, Brazil). After pre-cooling, the juice samples were extracted using an industrial extractor (ES4EA-B60000 Croydon, Duque de Caxias, Brazil) to perform the chemical and chromatographic analyses.

\subsection{Physicochemical analysis}

The physical characteristics of fruit were evaluated, determining the fruit mass ( $\mathrm{g}$ ) with a semi-analytic scale (M505 Bel, Piracicaba, Brazil). A digital caliper (ABS Mitutoyo, Kawasaki, Japan) measured the longitudinal diameter $(\mathrm{mm})$ and equatorial diameter $(\mathrm{mm})$. Peel color was obtained by the Hue angle $\left(h^{\circ}\right)$ means for each sample, using mean values for red-green $\left(a^{*}\right)$ and yellow-blue $\left(b^{*}\right)$ measured with a digital colorimeter (CR-10 Konica Minolta, Tokyo, Japan), considering three measure points in the equatorial surface of each fruit. Hue angle was determined according to McGuire (1992). Then, the juice yield was obtained by the ratio between juice mass and fruit mass (Tazima et al., 2014).

Fruit samples were also characterized according to their chemical profile. A digital refractometer with automatic temperature compensation (DR301-95 Krüss Optronic, Hamburg, Germany) was used to determine soluble solids (SS) contents, the result was expressed as ${ }^{\circ}$ Brix. Titratable acidity (TA) was assessed by titration with a standard $0.1 \mathrm{~N} \mathrm{NaOH}$ solution in a semi-automatic titrator, the results were expressed in 
percentage of citric acid (Gaithersburg \& Horwitz, 1990). The ratio was determined by the relation between soluble solids (SS) and titratable acidity (TA).

\subsection{Chromatographic analysis}

For HPLC analysis, $5 \mathrm{ml}$ of freshly squeezed juice mixed with $15 \mathrm{ml}$ of ultra-pure water (Milli-Q) were centrifuged at $50000 \mathrm{rpm}$ in a centrifuge (CP100WX Hitachi, Tokyo, Japan) for $10 \mathrm{~min}$, the supernatant was then filtered through $0.22 \mu \mathrm{m}$ pore size membrane filters (Sartorius Stedim Biotech, Goettingen, Germany).

The determination of organic acids and carbohydrates were performed by HPLC instrumental system (LC-20 A Shimadzu, Kyoto, Japan) equipped with a high-pressure pump system (LC-20AT), the automatic injector (SIL-20AC HT), refractive index detector (RID-10A), photodiode array (SPD-M20A), column oven (CTO-20A) and control module (CBM-20A). Data collection and integration of chromatographic peaks were computed processed by the LC Solutions software (Shimadzu, Kyoto, Japan).

\subsubsection{Organic acids}

The centrifuged and filtered samples were vialed and injected into the HPLC system. The injection volume used was $20 \mu \mathrm{L}$. Organic acids were analyzed onto a Phenomenex C1 8 column $(250 \times 4.6 \mathrm{~mm}$, particle size $5 \mu \mathrm{m})$ (Phenomenex, Torrance, USA). The mobile phase consisted of $25 \mathrm{mM}$ sodium phosphate buffer solution, and $\mathrm{pH}$ adjusted to 2.4 with phosphoric acid at a flow of $1.0 \mathrm{~mL} \mathrm{~min}{ }^{-1}$. The column was kept at $30^{\circ} \mathrm{C}$ with refractive index detection (RID -10A).

\subsubsection{Carbohydrates}

Samples of $2 \mathrm{~mL}$ of orange juice were used to determine carbohydrates, previously centrifuged, and filtered. Solid-phase extraction was performed passing samples through a Sep-Pak C18 $500 \mathrm{mg}$ cartridge after activated with $2 \mathrm{~mL}$ of methanol and $4 \mathrm{~mL}$ of ultra-pure water (Milli-Q). The eluate was collected and filtered through a $0.22 \mu \mathrm{m}$ membrane filter (Sartorius Stedim Biotech, Goettingen, Germany). The HPLC system received $20 \mu \mathrm{m}$ of the sample. Sugars were analyzed using a Shim-pack CLC-NH2 (M) column $(250 \times 4.6 \mathrm{~mm}$, particle size $5 \mu \mathrm{m})$ (Shimadzu, Kyoto, Japan) kept at $30{ }^{\circ} \mathrm{C}(\mathrm{CTO}-10 \mathrm{AS}$ VP). The used mobile phase was a mixture of acetonitrile: water 75:25 (v/v) at a flow of $1.0 \mathrm{~mL} \mathrm{~min}^{-1}$, according to Pauli et al. (2011).

\subsection{Statistical analysis}

All analyses were performed in triplicate in a complete randomized design with five treatments (fruit from different rootstocks). Data were processed by the R 3.4.1 version (The R Foundation for Statistical Computing, Vienna) and assayed according to the experiment design, using analysis of variance followed by Tukey's test $(p \leq 0.05)$.

\section{Results and Discussion}

\subsection{Physicochemical analysis}

Fruit from 'Salustiana' sweet orange was first characterized according to its physical characteristics (Table 1 and Figure 1). The results showed that ' $\mathrm{C}-13$ ' citrange rootstock induced production of large-sized fruit, presenting fruit mass of $222 \mathrm{~g}$, longitudinal and equatorial diameters of 72 and $77 \mathrm{~mm}$, respectively. These values were significantly greater than those noticed in oranges from 'Cleopatra' mandarin, which resulted in fruit of small caliper with $163 \mathrm{~g}$ per fruit and longitudinal and equatorial diameter of 65 and $68 \mathrm{~mm}$, respectively. 
Determination of organic acids and carbohydrates in 'Salustiana' orange fruit from different rootstocks

Carvalho, D. U. et al.

Table 1. Fruit physical characteristics from 'Salustiana' sweet oranges tree grafted onto five rootstocks.

\begin{tabular}{|c|c|c|c|c|}
\hline \multirow[t]{2}{*}{ Rootstocks } & \multicolumn{4}{|c|}{$\begin{array}{l}\text { Fruit physical characteristics } \\
\text { Mean } \pm \text { SD }\end{array}$} \\
\hline & Fruit mass (g) a & $\mathbf{L D}(\mathbf{m m})^{a}$ & ED $(\mathbf{m m})^{a}$ & Color $\left(h^{o}\right)^{\text {ns }}$ \\
\hline 'Rangpur' lime & $186 \pm 9.0 \mathrm{bc}$ & $69 \pm 1.2 \mathrm{a}$ & $72 \pm 1.5 \mathrm{bc}$ & $82.8 \pm 1.4$ \\
\hline 'Cleopatra' mandarin & $163 \pm 6.5 \mathrm{c}$ & $65 \pm 1.7 b$ & $68 \pm 0.8 \mathrm{c}$ & $84.9 \pm 0.4$ \\
\hline 'Sunki' mandarin & $200 \pm 14.7 \mathrm{ab}$ & $70 \pm 1.7 \mathrm{a}$ & $73 \pm 2.7 \mathrm{ab}$ & $81.6 \pm 1.6$ \\
\hline 'Swingle' citrumelo & $196 \pm 13.8 \mathrm{ab}$ & $69 \pm 1.9 \mathrm{a}$ & $73 \pm 1.9 \mathrm{ab}$ & $83.4 \pm 2.4$ \\
\hline ' $\mathrm{C}-13$ ' citrange & $222 \pm 7.8 \mathrm{a}$ & $72 \pm 0.5 \mathrm{a}$ & $77 \pm 1.4 \mathrm{a}$ & $82.7 \pm 2.0$ \\
\hline Mean & 193 & 69 & 73 & 83.1 \\
\hline CV (\%) & 5.6 & 2.2 & 2.5 & 2.1 \\
\hline
\end{tabular}

LD - Longitudinal diameter; ED - Equatorial diameter. ${ }^{a}$ Means followed by the same letter in the columns do not differ statistically according to Tukey's test $(p \leq 0.05)$. ${ }^{\text {ns }}$ Non-significant at 0.05 level.
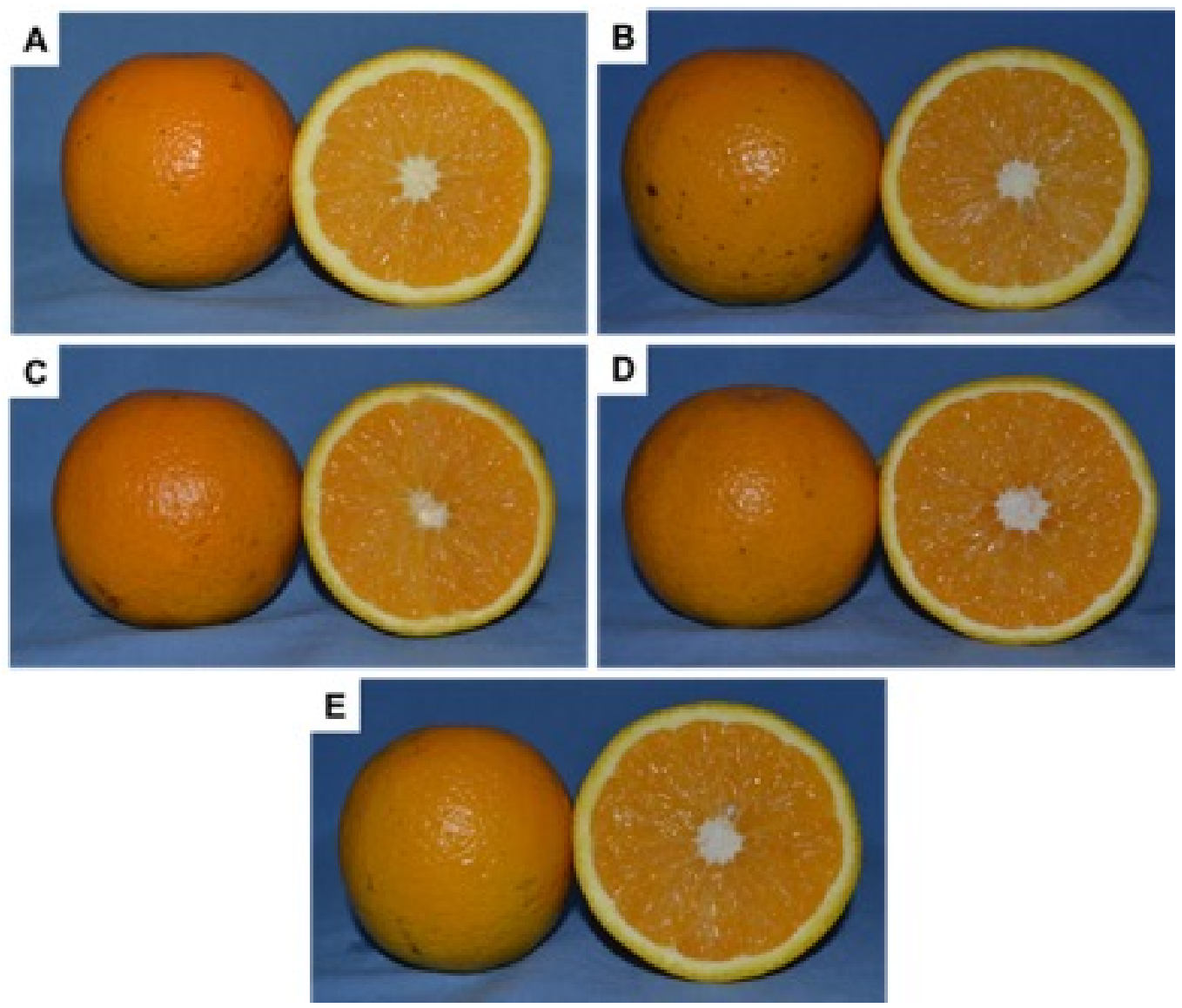

Figure 1. Fruit from 'Salustiana' oranges tree [Citrus sinensis (L.) Osb.] grafted onto different rootstocks: (A)

'Rangpur' lime (C. limonia Osb.); (B) 'Cleopatra' mandarin (C. reshni Hort. ex Tanaka); (C) 'Sunki' mandarin (C. sunki Hort. ex Tanaka); (D) 'Swingle' citrumelo [C. paradisi Macf. cv. Duncan $\times$ Poncirus trifoliata (L.) Raf.]; and (E) 'C-13' citrange [C. sinensis (L.) Osb. $\times$ P. trifoliata (L.) Raf.].

These values are greater than those observed by Siqueira et al. (2007) and Bini et al. (2009) evaluating the same cultivar in Valencia (Spain) and Uruguaiana (Brazil). Siqueira et al. (2007) recorded $46 \mathrm{~g}$ per fruit with $46 \mathrm{~mm}$ of diameter at the end of their experiment; while Bini et al. (2009) noticed fruit weight varying from 
128 to $139 \mathrm{~g}$ with diameters between 64 and $68 \mathrm{~mm}$, depending on the crop season. On the other hand, our findings were related to those found by Santos et al. (2010), characterizing eight seedless varieties of citrus produced in Viçosa (Brazil), in which 'Salustiana' orange fruit ranked $160 \mathrm{~g}$ with diameters between 68 and $70 \mathrm{~mm}$. This was similar to other authors who assessed the influence of rootstocks under different citrus cultivars as 'Valencia' orange (Auler et al., 2008), 'Okitsu' Satsuma mandarin (Tazima et al., 2013), and 'Jaffa' orange (Bacar et al., 2017). As observed in the present study, larger and heavier fruit may present greater demand in the market since Brazilian consumers have a preference for large size fruit (Pio et al., 2001).

Concerning peel color, the tested rootstocks did not influence this aspect. Flavedo color was based on the Hue angle that demonstrates its changes, values closest to $90 h^{\circ}$ indicates a high yellowish content in the peel, as observed for this cultivar which ranged from 81.6 to $84.9 h^{\circ}$ according to the rootstock. This color change occurs due to the chlorophyll degradation and synthesis of carotenoids, responsible for the yellow or orange color of the flavedo (Ladaniya, 2008; Santos et al., 2010). In general, all treatments presented fruit with adequate peel color based on the international and domestic standards of table citrus (Organisation for Economic Co-operation and Development, 2010; Companhia de Entrepostos e Armazéns Gerais de São Paulo, 2011).

Table 2 shows the juice yield and chemical composition of 'Salustiana' orange juice. We observed a significant difference between juice yield and soluble solids contents parameters. 'Swingle' citrumelo and 'Sunki' mandarin rootstocks induced higher juice content for this cultivar, as reported by Santos et al. (2010) in fruit from 'Salustiana' orange and 'Swingle' citrumelo combination. In addition, the evaluated treatments were superior in juice yield than those observed by Bini et al. (2009), 39\%; and also, higher than the minimum juice content required by the Organisation for Economic Co-operation and Development (2010) and the Companhia de Entrepostos e Armazéns Gerais de São Paulo (2011), 35 and 45\% respectively.

Table 2. Juice yield and fruit chemical composition from 'Salustiana' sweet orange tree grafted onto five rootstocks.

\begin{tabular}{|c|c|c|c|c|}
\hline \multirow{2}{*}{ Rootstocks } & \multicolumn{4}{|c|}{$\begin{array}{c}\text { Fruit physical characteristics } \\
\text { Mean } \pm \text { SD }\end{array}$} \\
\hline & $\begin{array}{l}\text { Juice Yield } \\
(\%)^{a}\end{array}$ & $\begin{array}{c}\text { SS } \\
\left({ }^{\circ} \text { Brix }\right)^{a}\end{array}$ & $\begin{array}{c}\text { TA } \\
(\% \text { citric acid })^{n s}\end{array}$ & $\begin{array}{c}\text { Ratio } \\
\text { (SS/TA) }^{n s}\end{array}$ \\
\hline 'Rangpur' lime & $47.2 \pm 1.1 \mathrm{~b}$ & $11.1 \pm 0.3 \mathrm{a}$ & $0.75 \pm 0.02$ & $14.7 \pm 0.3$ \\
\hline 'Cleopatra' mandarin & $47.6 \pm 1.1 \mathrm{~b}$ & $9.3 \pm 0.1 \mathrm{c}$ & $0.71 \pm 0.04$ & $13.1 \pm 0.7$ \\
\hline 'Sunki' mandarin & $48.9 \pm 2.1 \mathrm{ab}$ & $9.9 \pm 0.2 \mathrm{~b}$ & $0.68 \pm 0.04$ & $14.6 \pm 1.0$ \\
\hline 'Swingle' citrumelo & $50.5 \pm 1.6 \mathrm{a}$ & $10.3 \pm 0.3 \mathrm{~b}$ & $0.77 \pm 0.09$ & $13.3 \pm 1.4$ \\
\hline 'C-13' citrange & $46.9 \pm 1.2 b$ & $9.1 \pm 0.2 \mathrm{c}$ & $0.70 \pm 0.03$ & $13.1 \pm 0.8$ \\
\hline Mean & 48.2 & 9.9 & 0.72 & 13.8 \\
\hline CV (\%) & 1.7 & 2.2 & 7.2 & 6.6 \\
\hline
\end{tabular}

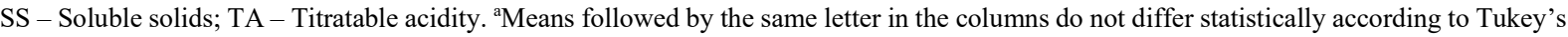

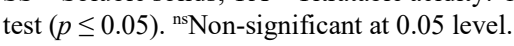

Regarding soluble solids content, 'Rangpur' lime reached the highest value (11 'Brix) for 'Salustiana' orange fruit, differing from the other treatments. This characteristic agrees to Stenzel et al. (2006), who reported an early maturation in fruit from 'Folha Murcha' sweet orange tree onto 'Rangpur' lime, comparing to other rootstocks. The range between our treatments was 9 to $11^{\circ} \mathrm{Brix}$, indicating a suitable quality for harvest since fruit should present at least $9{ }^{\circ}$ Brix as soluble solids content in its juice (Pereira et al., 2006). As soluble solids content, titratable acidity can also be used to predict the maturation degree of fruit. These 
indices were similar among the treatments ranging from 0.68 to 0.77 and considered adequate according to Pereira et al. (2006). Because fully mature fruit of sweet oranges must present titratable acidity, expressed as citric acid, between 0.5 and $1.0 \%$. The ratio (soluble solids:acidity), which indicates the fruit maturation index, was similar for all tested treatments (rootstocks) varying from 13.1 to 14.7. These indices are close to those reported by Bini etal. (2009) and Castle \& Baldwin (2011) for the same cultivar, 11.5 and 12.8 respectively.

Environmental conditions and crop managements are among the major factors that influence fruit quality during its growth. For example, high temperatures contribute to the chlorophyll degradation and accumulation of soluble solids in the pulp (Ladaniya, 2008; Santos et al., 2010), while water availability regulates juice content and manages fruit production. Despite some differences, the evaluated rootstocks induced adequate physicochemical parameters for 'Salustiana' sweet oranges, meeting the minimum requirement of the international and domestic fresh market (Organisation for Economic Co-operation and Development, 2010; Companhia de Entrepostos e Armazéns Gerais de São Paulo, 2011).

\subsection{Organic acids composition in orange juice}

Table 3 describes the determination and quantification of organic acids. We did not observe significant differences among the treatments. Organic acids showed a total average of $737 \mathrm{mg} 100 \mathrm{~mL}^{-1}$ of the juice of 'Salustiana' sweet orange, in which citric acid was the major organic acid identified in the juice ranging from 602.4 to $735.1 \mathrm{mg} 100 \mathrm{~mL}^{-1}$ of orange juice, depending on the rootstock. These findings agree to Kelebek et al. (2009), Nour et al. (2010), Kafkas et al. (2011), Kelebek \& Selli (2011) and Scherer et al. (2012), who quantified citric acid as the major organic acid in sweet orange juices [C. sinensis (L.) Osb.].

Table 3. Organic acids composition in fruit from 'Salustiana' sweet orange tree grafted onto five rootstocks.

\begin{tabular}{cccc}
\hline \multirow{2}{*}{ Rootstocks } & \multicolumn{3}{c}{$\begin{array}{c}\text { Organic acids (mg 100 } \mathbf{~ m L}^{-1} \text { of orange juice) } \\
\text { Mean } \pm \text { SD }\end{array}$} \\
\cline { 2 - 4 } & Citric acid ${ }^{\text {ns }}$ & Ascorbic acid ${ }^{\text {ns }}$ & Total ns,a \\
\hline 'Rangpur' lime & $735.1 \pm 52.5$ & $58.4 \pm 5.4$ & $799.0 \pm 57.4$ \\
\hline 'Cleopatra' mandarin & $602.4 \pm 23.1$ & $56.3 \pm 6.3$ & $663.9 \pm 27.8$ \\
\hline 'Sunki' mandarin & $659.4 \pm 63.6$ & $60.9 \pm 1.8$ & $725.9 \pm 65.6$ \\
\hline 'Swingle' citrumelo & $665.4 \pm 89.9$ & $56.2 \pm 5.0$ & $726.7 \pm 89.2$ \\
\hline 'C-13' citrange & $733.6 \pm 39.4$ & $58.4 \pm 8.3$ & $797.4 \pm 47.1$ \\
\hline Mean & 679.2 & 58.0 & 737.2 \\
\hline CV (\%) & 8.6 & 9.9 & 8.2 \\
\hline
\end{tabular}

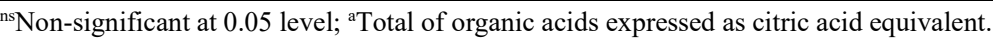

Kelebek et al. (2009) found $1266 \mathrm{mg}$ of citric acid in $100 \mathrm{~mL}$ of orange juice produced in Turkey, close to those reported by Nour et al. (2010) notifying a concentration of $1392 \mathrm{mg} 100 \mathrm{~mL}^{-1}$ in Romania. Contrasting these values, Scherer et al. (2012) reported concentration of citric acid between 517 and $529 \mathrm{mg} 100 \mathrm{~mL}^{-1}$ of orange juice produced in Brazil, close to the values obtained in the present study (602 to $735 \mathrm{mg} 100 \mathrm{~mL}^{-1}$ ) indicating that the concentration of organic acid, like other components, is dependent of the local environment (Lado et al., 2014).

Now, ascorbic acid levels ranged from 56.2 to $60.9 \mathrm{mg} 100 \mathrm{~mL}^{-1}$ of orange juice, similar to the values quantified by Kelebek et al. (2009) and Nour et al. (2010) for sweet orange, 49.0 and $63.6 \mathrm{mg} 100 \mathrm{~mL}^{-1}$ respectively. But higher than those noticed by Meléndez-Martínez et al. (2007) who described an average of 
ascorbic acid equal to $39.1 \mathrm{mg} 100 \mathrm{~mL}^{-1}$ in 'Valencia' orange juice produced in Spain; and Legua et al. (2014) describing concentrations of $27 \mathrm{mg} 100 \mathrm{~g}^{-1}$ of fresh weight of fruit from 'Clemenules' mandarin tree grafted onto 'Cleopatra' mandarin and 'Swingle' citrumelo cultivated in Portugal.

However, the level of ascorbic acid appears to be variable in citrus fruit due to the variability between cultivars and species. Fruit of 'Mexerica do Rio' produced in Viçosa (Brazil) presented high amount of ascorbic acid in its juice, about $115 \mathrm{mg} 100 \mathrm{~g}^{-1}$ of juice (Silva et al., 2011); superior to the level mentioned above and those reported by Machado et al. (2017) for fruit from 'Tahiti' acid lime trees grafted on

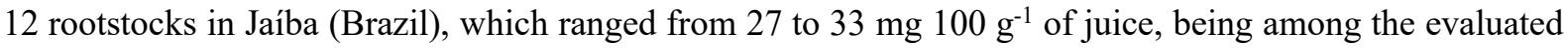
rootstock the 'Rangpur' lime, 'Swingle' citrumelo, 'Cleopatra' mandarin, and 'Sunki' mandarin. It indicates that the quantification of ascorbic acid is dependent on the cultivar associated with the managements and local environment. Thus, it is essential knowing the concentration of this organic acid in orange, because it is an important antioxidant and its concentration may indicate the quality of citrus juice (Kelebek et al., 2009; Legua et al., 2014), being the main biologically active form of vitamin $\mathrm{C}$ and can eliminate several free radicals (Davey et al., 2000; Scherer et al. 2012).

\subsection{Sugar composition in orange juice}

Despite the differences verified in the total soluble solids content of the evaluated treatments (Table 2), we did not notice significant differences among them for the concentration of carbohydrates (Table 4). There were three major sugar components in 'Salustiana' orange juice samples: sucrose, glucose, and fructose, just as described in previous studies regarding different citrus varieties (Cancalon, 1994; Kelebek et al., 2009; Kafkas et al., 2011; Kelebek \& Selli, 2011).

Table 4. Sugar composition in fruit from 'Salustiana' sweet orange tree grafted onto five rootstocks.

\begin{tabular}{|c|c|c|c|c|c|}
\hline \multirow{2}{*}{ Rootstocks } & \multicolumn{5}{|c|}{$\begin{array}{c}\text { Carbohydrates (mg.100 } \mathrm{mL}^{-1} \text { of orange juice) } \\
\text { Mean } \pm \mathrm{SD}\end{array}$} \\
\hline & Sucrose ${ }^{\text {ns }}$ & Glucose $\mathbf{n s}^{\text {s }}$ & Fructose ${ }^{\text {ns }}$ & Ratio $^{\text {ns,a }}$ & Total ${ }^{\text {ns,b }}$ \\
\hline 'Rangpur' lime & $1654.8 \pm 151$ & $819.3 \pm 48$ & $949.7 \pm 42$ & $0.86 \pm 0.01$ & $5016.0 \pm 322$ \\
\hline 'Cleopatra' mandarin & $1568.7 \pm 95$ & $746.0 \pm 45$ & $882.3 \pm 51$ & $0.85 \pm 0.01$ & $4662.7 \pm 277$ \\
\hline 'Sunki' mandarin & $1528.8 \pm 102$ & $784.8 \pm 26$ & $913.2 \pm 24$ & $0.86 \pm 0.01$ & $4755.2 \pm 190$ \\
\hline 'Swingle' citrumelo & $1686.0 \pm 35$ & $775.9 \pm 56$ & $893.5 \pm 65$ & $0.87 \pm 0.01$ & $4858.1 \pm 256$ \\
\hline 'C-13' citrange & $1704.4 \pm 76$ & $820.4 \pm 50$ & $943.5 \pm 63$ & $0.87 \pm 0.05$ & $5056.0 \pm 130$ \\
\hline Mean & 1628.5 & 789.3 & 916.4 & 0.86 & 4869.6 \\
\hline $\mathrm{CV}(\%)$ & 6.1 & 5.9 & 5.6 & 3.0 & 5.0 \\
\hline
\end{tabular}

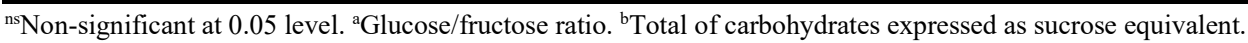

According to Silva et al. (1999) and Lee \& Coates (2000), these carbohydrates represent more than $80 \%$ of the total soluble solids content presented in orange juice. The ratio between these compounds is generally 2:1:1, sucrose: glucose: fructose respectively. Similar ratio was observed in our study for 'Salustiana' orange juice. It is considered typical for commercial orange juices according to Zhang \& Ritenour (2016) and is consistent to those described in other reports for orange cultivars (Lee \& Coates, 2000; Kelebek et al., 2009; Kelebek \& Selli, 2011; Kafkas et al., 2011).

The average of the total amount of carbohydrates was $4870 \mathrm{mg} 100 \mathrm{~mL}^{-1}$ of orange juice. The major identified carbohydrate was sucrose ranging from 1528.8 to $1704.4 \mathrm{mg} 100 \mathrm{~mL}^{-1}$ of orange juice, just as observed by Kelebek et al. (2009) for 'Kozan' sweet orange. In general, sucrose was responsible for $48.8 \%$ 
of the total sugar content followed by fructose $(27.5 \%)$ and glucose $(23.7 \%)$. The total sugar content is consistent with those reported by Lee \& Coates (2000) for 'Valencia' sweet orange (50.5\% sucrose, $23.7 \%$ glucose, and 25.8\% fructose), and Kelebek \& Selli (2011) for 'Dortyol' sweet orange (42.0\% sucrose, $28.1 \%$ glucose, and 29.9\% fructose). However, Legua et al. (2014) determined different sucrose:glucose:fructose ratio in fruit from 'Clemenules' mandarin trees grafted onto 'Cleopatra' mandarin (8:1:1) and 'Swingle' citrumelo (7:1:1), contrasting to the usual ratio described by Cancalon (1994) for fresh-squeezed juices $(2: 1: 1)$.

The glucose:fructose ratio for the samples was also performed because it allows us to determine the quality and authenticity of orange juices (Kelebek \& Selli, 2011). According to these authors, this ratio should present indices between 0.85 and 1.00 since orange fruit contains similar quantities of fructose and glucose, or even a slight increase in fructose, just as observed in our study for 'Salustiana' orange juice and for juice produced from different cultivars in the United States (Zhang \& Ritenour, 2016). Thus, orange juice must present this pattern $(0.85-1.00)$ as a sugar constituent for the citrus industry, if not, an adulteration should be considered (Lee \& Coates, 2000).

The glucose:fructose ratio ranged from 0.85 to 0.87 in 'Salustina' orange samples. These values were between those described by Zhang \& Ritenour (2016) for 286 samples of orange juice produced in four States of the United States (0.8-0.9). They are also close to those observed by Kelebek \& Selli, (2011) for 'Dortyol' oranges in Turkey (0.94), and lower than the maximum values required by the European Union legislation (1.03). It attends the orange juice requirement with regards to quality, authenticity, and identity because most of all produced juice in Brazil, as frozen concentrated orange juice (FCOJ), is exported to these countries (Lado et al., 2014; Kelebek \& Selli, 2011).

In summary, despite the similarity among the evaluated treatments, the concentration, and composition of organic acids and carbohydrates may differ according to the citrus variety, soil-climate conditions, season, stress condition, fruit maturity, juice processing, crop and postharvest management as described in the literature (Cancalon, 1994; Jones, 1998; Rekha et al., 2012; Lado et al., 2014). However, the tested rootstocks do not appear to influence the organic acids and carbohydrates contents in 'Salustiana' sweet oranges.

\section{Conclusions}

'Salustiana' oranges produced on all evaluated rootstocks presents adequate physicochemical parameters, attending the quality standards for the citrus industry. 'C-13' citrange induces production of larger and heavier fruit. Significant differences were not observed between the treatments regarding organic acid and carbohydrate concentrations. As organic acids, citric and ascorbic acids were identified in the samples. The sugar composition consisted of sucrose, glucose, and fructose (1:1:2). The results regarding sugars and organic acids concentration characterize the evaluated cultivar, providing information about nutrition and the quality of fruit produced onto different rootstocks.

\section{Acknowledgement}

This work was supported by the Coordenação de Aperfeiçoamento de Pessoal de Nível Superior (CAPES) and the Conselho Nacional de Desenvolvimento Científico e Tecnológico (CNPq).

\section{References}

Auler, P. A. M., Fiori-Tutida, A. C. G., \& Tazima, Z. H. (2008). Comportamento da laranjeira 'Valência' sobre seis porta-enxertos no Noroeste do Paraná. Revista Brasileira de Fruticultura, 30(1), 229-234. http://dx.doi.org/10.1590/S010029452008000100042

Bacar, E. L. C., Neves, C. S. V. J., Leite Junior, R. P., Yada, I. F. U., \& Tazima, Z. H. (2017). 'Jaffa' sweet orange plants grafted onto five rootstocks. Revista Brasileira de Fruticultura, 39(5), 1-9. http://dx.doi.org/10.1590/0100-29452017200 
Bini, D. A., Martins, C. R., Amaral, U., Brixner, G. F., \& Oliveira, D. B. (2009). Comportamento agronômico de tangerineira 'Clemenules' e de laranjeira 'Salustiana' no município de Uruguaiana-RS. Revista da FZVA, 16(2), 288-301.

Cancalon, P. F. (1994). Changes in the saccharide composition of citrus juice and anatomical fractions during fruit maturation. Proceedings of the Florida State Horticultural Society. 107, 253-256.

Cantuarias-Avilés, T., Mourão Filho, F. A. A., Stuchi, E. S., Silva, S. R., \& Espinoza-Núñez, E. (2010). Tree performance and fruit yield and quality of 'Okitsu' Satsuma mandarin grafted on 12 rootstocks. Scientia Horticulturae, 123(3), 318-322. http://dx.doi.org/10.1016/j.scienta.2009.09.020

Castle, W. S. (2010). A career perspective on Citrus rootstocks, their development, and commercialization. HortScience, 45(1), 11-15. http://dx.doi.org/10.21273/HORTSCI.45.1.11

Castle, W. S., \& Baldwin, J. C. (2011). Young-tree performance of juvenile sweet orange scions on Swingle citrumelo rootstock. HortScience, 46(4), 541-552. http://dx.doi.org/10.21273/HORTSCI.46.4.541

Companhia de Entrepostos e Armazéns Gerais de São Paulo - CEAGESP. (2011). Centro de Qualidade em Horticultura: Programa Brasileiro para a melhoria dos padrões comerciais e embalagens de hortigranjeiros (11 p.). Campinas: CEAGESP.

Davey, M. W., Montagu, M. V., Sanmartin, D. I. M., Kanellis, A., Smirnoff, N., Benzie, I. J. J., Strain, J. J., Favell, D., \& Fletcher, J. (2000). Plant L-ascorbic acid: Chemistry, function, metabolism, bioavailability and effects of processing. Journal of the Science of Food and Agriculture, 80, 825-860. http://dx.doi.org/10.1002/(SICl)1097-0010(20000515)80:7<825::AIDJSFA598>3.0.CO;2-6

Food and Agriculture Organization Corporate Statistical Database - FAOSTAT. (2018). FAOSTAT: Statistical Database. Retrieved in 2018, July 03, from http://www.faostat.fao.org

Gaithersburg, G. L., \& Horwitz, W. K. (Ed.). (1990). Official methods of analysis of the Association of Official Analytical Chemists. Arlington: AOAC.

Gonzatto, M. P., Kovaleski, A. P., Brugnara, E. C., Weiler, R. L., Sartori, I. A., Lima, J. G., Bender, R. J., \& Schwarz, S. F. (2011). Performance of 'Oneco' mandarin on six rootstocks in South Brazil. Pesquisa Agropecuária Brasileira, 46(4), 406-411. http://dx.doi.org/10.1590/S0100-204X2011000400010

Jones, D. L. (1998). Organic acids in the rhizosphere a critical review. Plant and Soil, 205(1), 25-44.

http://dx.doi.org/10.1023/A:1004356007312

Kafkas, E. S., Polatöz, S., \& Koç, N. (2011). Quantification and comparison of sugars, carboxylic acids and vitamin C components of various citrus species by HPLC techniques. Journal of Agricultural Science and Technology, 5(2), 175-180.

Kelebek, H., Selli, S., Canbas, A., \& Cabaroglu, T. (2009). HPLC determination of organic acids, sugars, phenolic compositions and antioxidant capacity of orange juice and orange wine made from a Turkish cv. Kozan. Microchemical Journal, 91(2), 187192. http://dx.doi.org/10.1016/j.microc.2008.10.008

Kelebek, H., \& Selli, S. (2011). Determination of volatile, phenolic, organic acid and sugar components in a Turkish cv. Dortyol (Citrus sinensis L. Osbeck) orange juice. Journal of the Science of Food and Agriculture, 91(10), 1855-1862. PMid:21480267. http://dx.doi.org/10.1002/jsfa.4396

Ladaniya, M. S. (2008). Citrus fruit: Biology, technology and evaluation (576 p.). San Diego: Academic Press.

Lado, J., Rodrigo, J. M., \& Zacarias, L. (2014). Maturity indicators and citrus fruit quality. Stewart Postharvest Review, 2(2), 1-6.

Lee, H. S., \& Coates, G. A. (2000). Quantitative study of free sugars and myo-inositol in citrus juices by HPLC and literature compilation. Journal of Liquid Chromatography \& Related Technologies, 23(14), 2123-2141. http://dx.doi.org/10.1081/JLC100100476

Legua, P., Bellver, R., Forner, J. B., \& Forner-Giner, M. A. (2011). Plant growth yield and fruit quality of 'Lane Late' navel orange on four citrus rootstocks. Spanish Journal of Agricultural Research, 9(1), 271-279. http://dx.doi.org/10.5424/sjar/20110901-17210

Legua, P., Forner, J. B., Hernández, F., \& Forner-Giner, M. A. (2014). Total phenolics, organic acids, sugars and antioxidant activity of mandarin (Citrus clementina Hort. ex Tan.): variation from rootstock. Scientia Horticulturae, 174, 60-64. http://dx.doi.org/10.1016/j.scienta.2014.05.004

Machado, D. L., Siqueira, D. L., Salomão, L. C. C., Cecon, P. R., \& Silva, D. F. P. (2017). Evaluation of rootstocks for 'Tahiti' acid lime in northern state of Minas Gerais. Revista Brasileira de Fruticultura, 39(1), e-790. http://dx.doi.org/10.1590/010029452017790

McGuire, R. G. (1992). Reporting of objective color measurements. HortScience, 27(12), 1254-1255. http://dx.doi.org/10.21273/HORTSCI.27.12.1254

Meléndez-Martínez, A. J., Vicario, I. M., \& Heredia, F. J. (2007). Carotenoids, color, and ascorbic acid content of a novel frozenmarketed orange juice. Journal of Agricultural and Food Chemistry, 55(4), 1347-1355. PMid:17253722. http://dx.doi.org/10.1021/jf063025b

Nour, V., Trandafir, I., \& Ionica, M. E. (2010). HPLC organic acid analysis in different citrus juices under reversed phase conditions. Notulae Botanicae Horti Agrobotanici Cluj-Napoca, 38(1), 44-48. http://dx.doi.org/10.15835/nbha3814569

Organisation for Economic Co-operation and Development - OECD. (2010). International standards for fruit and vegetables: Citrus fruit (244 p). Paris: OECD.

Pauli, E. D., Cristiano, V., \& Nixdorf, S. L. (2011). Method for determination of carbohydrates employed in the selection of adulterations in coffee. Quimica Nova, 34(4), 689-694. http://dx.doi.org/10.1590/S0100-40422011000400023 
Pereira, M. E. C., Cantillano, F. F., Gutierez, A. S. D., \& Almeida, G. V. B. (2006). Postharvest procedures in integrated production of citrus (40 p.). Cruz das Almas: EMBRAPA.

Pio, R. M., Minami, K., \& Figueiredo, J. O. (2001). Características do fruto da variedade Span Americana (Citrus reticulata Blanco): uma tangerina do tipo Poncã de maturação precoce. Revista Brasileira de Fruticultura, 23(2), 325-329. http://dx.doi.org/10.1590/S0100-29452001000200025

Rekha, C., Poornima, G., Manasa, M., Abhipsa, V., Devi, J. P., Kumar, H. T. V., \& Kekuda, T. R. P. (2012). Ascorbic acid, total phenol content and antioxidant activity of fresh juices of four ripe and unripe citrus fruits. Chemical Science Transactions, 1(2), 303-310. http://dx.doi.org/10.7598/cst2012.182

Santos, D., Matarazzo, P. H. M., Silva, D. F. P., Siqueira, D. L., Santos, D. C. M., \& Lucena, C. C. (2010). Caracterização físicoquímica de frutos cítricos apirênicos produzidos em Viçosa, Minas Gerais. Ceres, 57(3), 393-400. http://dx.doi.org/10.1590/S0034-737X2010000300016

Scherer, R., Rybka, A. C. P., Ballus, C. A., Meinhart, A. D., Filho, J. T., \& Godoy, H. T. (2012). Validation of a HPLC method for simultaneous determination of main organic acids in fruits and juices. Food Chemistry, 135(1), 150-154. PMid:26434274. http://dx.doi.org/10.1016/j.foodchem.2012.03.111

Silva, M. B. M., Seabra, R. M., Andrade, P. B., Oliveira, M. B., \& Ferreira, M. A. (1999). Adulteração por adição de açúcares a sumos de frutos: uma revisão. Food Science and Technology, 2(4), 184-191. http://dx.doi.org/10.1080/11358129909487600

Silva, D. F. P., Siqueira, D. L., Santos, D., Machado, D. L. M., \& Salomão, L. C. C. (2011). Recobrimentos comestíveis na conservação pós-colheita de 'Mexerica-do-Rio'. Revista Brasileira de Fruticultura, 33(1), 357-362. http://dx.doi.org/10.1590/S0100-29452011000500045

Silva, S. R., Stuchi, E. S., Girardi, E. A., Cantuarias-Avilés, T. E., \& Bassan, M. M. (2013). Desempenho da tangerineira 'Span americana' em diferentes porta-enxertos. Revista Brasileira de Fruticultura, 35(4), 1052-1058. http://dx.doi.org/10.1590/S010029452013000400016

Siqueira, D. L., Guardiola, J. L., \& Souza, E. F. M. (2007). Crescimento dos frutos de laranjeira 'Salustiana' situados em ramos anelados com diversas relações de folhas/frutos. Revista Brasileira de Fruticultura, 29(2), 228-232. http://dx.doi.org/10.1590/S0100-29452007000200008

Stenzel, N. M. C., Neves, C. S. V. J., Marur, C. J., Scholz, M. B. S., \& Gomes, J. C. (2006). Maturation curves and degree-days accumulation for fruits of 'Folha Murcha' orange trees. Scientia Agrícola, 63(3), 219-225. http://dx.doi.org/10.1590/S010390162006000300002

Tazima, Z. H., Neves, C. S. V. J., Yada, I. F. U., \& Leite Junior, R. P. (2013). Performance of 'Oktisu' Satsuma Mandarin on nine rootstocks. Scientia Agrícola, 70(6), 422-427. http://dx.doi.org/10.1590/S0103-90162013000600007

Tazima, Z. H., Neves, C. S. V. J., Yada, I. F. U., \& Leite Junior, R. P. (2014). Performance of 'Oktisu' Satsuma Mandarin trees on different rootstocks in Northwestern Paraná state. Semina: Ciências Agrárias, 35(5), 2297-2308. http://dx.doi.org/10.5433/1679-0359.2014v35n5p2297

Zhang, J., \& Ritenour, M. A. (2016). Sugar composition analysis of commercial citrus juice products. Proceedings of the Annual Meeting of the Florida State Horticultural Society, 129, 178-180.

Funding: Ministério da Ciência, Tecnologia e Inovação/Conselho Nacional de Desenvolvimento Científico e Tecnológico (CNPq) e Coordenação de Aperfeiçoamento de Pessoal de Nível Superior (CAPES) (88882.448335/2019-01). 